\title{
Peculiarities of Indian English as a separate language
}

\section{Características del inglés indio como idioma independiente}

\section{Elizaveta Georgievna Grishechko}

Candidate of philological sciences, Assistant Professor in the Department of Foreign Languages, Faculty of Economics, RUDN University, Moscow, Russia.

ORCID: https://orcid.org/0000-0002-0799-1471

\section{Gaurav Sharma}

Ph.D. student, Assistant Professor in the Department of Foreign Languages, Faculty of Economics, RUDN University, Moscow, Russia.

ORCID: https://orcid.org/0000-0002-3627-7859

\section{Kristina Yaroslavovna Zheleznova}

Ph.D. student, Assistant Professor in the Department of Foreign Languages, Faculty of Economics, RUDN University, Moscow, Russia.

ORCID: https://orcid.org/0000-0002-8053-703X

Received 02-12-20 Revised 04-25-20

\section{*Correspondence}

Email: ivannovadremova29@gmail.com
Accepted 01-13-21 On line 01-21-21

Cite as:

Grishechko, E., Sharma, G., Zheleznova, K. (2021). Peculiarities of Indian English as a separate language. Propósitos y Representaciones, 9 (SPE1), e913. Doi: http://dx.doi.org/10.20511/pyr2021.v9nSPE1.913

() Universidad San Ignacio de Loyola, Vicerrectorado de Investigación, 2021. 


\section{Summary}

The following paper will reveal the varieties of English pronunciation in India, its features and characteristics. This research helped us to consider the history of occurrence of English in India, the influence of local languages on it, the birth of its own unique English, which is used in India now. The research highlights the impact of English on Indians in general and its modification as the individual language differs from other English variants. The paper illustrates the features of translation and vocabulary in Indian English, which will explore the specification uses of it. The research also provides variations of Indian English as dialect and pronunciation in India because it changes from north to south and east to west. To complete our study, we used a lot of methods, such as observation, comparative, elicitation approaches, collection and analysis of diverse information. Such topic and results of this research could help us to learn the differences in language implementation in different countries and could give some ideas to improve teaching methods that are used in schools and universities all over the world. In conclusion, we found out that the English language has considerably changed since its occurrence, and all these transformations are results of globalisation, the realisation of new technologies, development of media and strengthening of communication between different countries.

Keywords: accents, American English, dialects, British English, Indian English, linguistic features, R.P., Received Pronunciation, translation.

\section{Resumen}

El siguiente artículo revelará las variedades de pronunciación del inglés en la India, sus características y características. Esta investigación nos ayudó a considerar la historia de aparición del inglés en la India, la influencia de los idiomas locales en él, el nacimiento de su propio inglés único, que se usa ahora en la India. La investigación destaca el impacto del inglés en los indios en general y su modificación a medida que el idioma individual difiere de otras variantes del inglés. El documento ilustra las características de la traducción y el vocabulario en inglés indio, que explorará los usos específicos de la misma. La investigación también proporciona variaciones del inglés indio como dialecto y pronunciación en la India porque cambia de norte a sur y de este a oeste. Para completar nuestro estudio, utilizamos una gran cantidad de métodos, como la observación, comparativos, enfoques de elicitación, recopilación y análisis de información diversa. Este tema y los resultados de esta investigación podrían ayudarnos a conocer las diferencias en la implementación del lenguaje en diferentes países y podrían dar algunas ideas para mejorar los métodos de enseñanza que se utilizan en escuelas y universidades de todo el mundo. En conclusión, descubrimos que el idioma inglés ha cambiado considerablemente desde su aparición, y todas estas transformaciones son resultado de la globalización, la realización de nuevas tecnologías, el desarrollo de los medios y el fortalecimiento de la comunicación entre diferentes países.

Palabras clave: acentos, inglés americano, dialectos, inglés británico, inglés indio, características lingüísticas, R.P., pronunciación recibida, traducción.

\section{Introducción}

Nowadays, India is a country, which is one of the multilingual countries in the world that has quite much different local languages. All these languages indicate India's long and various history. Throughout the last thousand years, India was jointed under other empires and divided into a lot of minor kingdoms. All this helped to extend mutual linguistic features in all local Indian languages, one of which could become leading in the country. Since 1947, when India attained independence from the Britishers, leaders of the state decided to choose Hindi as the official language, which would enable regional communication and support the nation's unity. Indian leaders thought through some problems that were essential in establishing a single language in multilingual society in India. 
Nevertheless, Hindi and English are still sharing their status as official languages. All this happened due to some unforeseen problems concerning tactical mistakes that were made by Hindi enthusiasts. Such errors led to strong counteractions between some groups who believed that the Hindi language was obligatory for them. (Joseph, 2011)

Such particular position suggests a curious occasion for the further analysis of such aspects of language planning and promotion as political and social. The interest refreshed in the research of national languages in India throughout detailed analyses of studies in terms of Indian English. Majority of Indians do not see English as a foreign language since they have become familiar with it. Hindi used as the main in some regions, at the same time with the combination of some local languages. People also recapped the fact that there is an immense deal of disapproval to Hindi in the southern parts of the country. (Baldridge, 1996)

All previous information brings us to some questions: what is the history of English in India? Why do people in India need a common language? How important is the role of English in India? What is the future of English?

We all know, that language is an essential tool for population, and it has great importance and implication in the country. The Census of India is the most robust basis of language information that was collected and published for a hundred years. Such language information is predominantly valuable for the people of India, where society asks about their ethnicity in terms of scheduled tribes (Indian tribal communities). (Census of India, 2011)

There are two national languages for some administrative commitments: Hindi and English. The first one, Hindi, is official and local, and this language is the main for communication in the country. Though there are even more local languages, people speak in different parts of India. Nevertheless, India still has no national languages. There are twenty-two regional languages that are approved by the Indian Constitution for other institutional purposes. According to the Indian Constitution, Article 343(1) declares "The official language of the Union shall be Hindi in Devanagari script. The use of the form of numerals for the official purposes of the Union shall be the international form of Indian numerals." (Constitution of India, 2015, p. 221) English and Hindi are the primaries in the business and Indian parliament. As for the English language, people use it for official purposes (for example, parliamentary proceedings, journalism, judiciary, broadcasting, education system, and communications between the Central Government and a State Government. The English language is everywhere starts with teacher, who speaks Hindi and gives his pupils some directions, for example, where they can meet and when a bus is leaving, and all these explanations are in English. All the above means that the English language pervades in their routine life. It is always expected, specifically in big cities. (Rai, 2017; Baldridge, 1996; Bansal, 1990)

The states across India have the right to indicate their different official language through legislation. Moreover, the constitution distinguishes twenty-two regional languages, including Hindi, as "scheduled languages". The Indian passport is a set of two languages, Hindi and English. (Ministry of Home Affairs, 2019, March 20)

This research aims to increase the awareness of global complications with English pronunciation for Indian English speakers. It will help to develop a shared understanding among people. Also, this research can improve the educational system concerning language studying.

\section{Materials and methods}

For this research, we studied all previous explorations in the field of English language diversity, accents, pronunciation and vocabulary. To begin our research process, we collected a massive amount of information about the history of the origin of English in India and its peculiarities. Our next step was to conduct this work we used observation, comparative, elicitation and translational 
approaches, collection and analysis of diverse information. Following previous actions, we concluded our work by understanding the spread of English, and we also found factual data, showing the percentage of Indians speaking it.

\section{Theoretical framework}

British English is considered as a standard English, which is spoken and written under British linguistic style. Many countries around the world follow it due to the impact of colonisation, for example, South Africa, Cyprus etc.

American English is a relatively separate dialect which is now a day considered as a particular language spoken in the USA and followed by many countries. English came to the United States in the 16th century and later on transformed as an independent language with its pronunciation, grammar, vocabulary, spelling, punctuation, idioms, and formatting of dates and numbers.

Indian English is a variety of British and American English with Indian spices, for example having its specific grammar, pronunciation, vocabulary etc. spoken in India along with Indian diaspora.

\section{A brief historical account of Indian English}

As discussed above, we know there are numerous diverse national languages spoken in India. All languages allocate multiple features such as vocabulary and grammatical structure. Hindi works as dominant for communication in India. Its origin is mostly in the northern part of India and widely used in almost every metropolitan. Let take into consideration southern regions, where local people communicate with the help of different languages that are not similar to Hindi. There is much more confrontation to it that opened the way for the English language to stay as a common language to a much greater degree. (R.L.G., 2011)

Forming one national language could help all Indian people to understand and work with each other in a quiet life. If people speak and use just one language, it improves the capability of people from different families to connect. When all local people use one language all over the country, it helps to unite nations and ease communication. English language could generally specify some essential fundamentals, the significant advantages and characteristics of real life. (Manivannan, 2019)

As we all know, English is an international language, and different researchers are continually following the evolution of the language in numerous countries. (Aleksandrova et al., 2017; Kharkovskaya et al., 2020; McGee, 2019)

Nowadays, the global society is multidimensional. India should decide without any hesitation, whether their national language is English or not. If we analyse the history, the English language was the only one that was dominating in India that extensively. English is widely spoken around the world where India is in a unique situation. Today, India has the status of the country, which has one of the largest English-speaking populations in the world.

In 1947, following the nation's independence from the British Empire, there were some struggles to raise the Hindi language as the national language; nevertheless, some regional linguistic sentiments were too high. In the southern part of the country, people protested against it and offered their local languages. Thus, Hindi became one of the two official languages, that could be used in the public and private institution among judiciary and parliament, as a compromise. (Manivannan, 2019) 
A constructive approach to the English language as a national language is significant for uniting people. It is undoubtedly vital that society agrees about the significance of English language skills. If a person can speak English, he will be understood anywhere in the world. This language has the leading role in media, telecommunication, radio and many other spheres of life. English has widely expended for inter-state communication and broadcasting over the country. No doubt, the impact of the English language is not remaining but is also growing.

The result of the research showed that the population was 97 crores $(1$ crore $=10.000 .000$ people) in India in 1997. Later, a survey conducted by "India Today" showed that just third of the whole population (about 32 crores), could keep up a conversation in the English language which has significantly increased since 1997 in schools. According to a report done by the C.I.A. (Central Intelligence Agency), the population exceeded 108 crores in July 2005. Approximately a third of the Indian population used the English language, which is much more than some people in English-speaking countries (such as Australia, U.S.A., U.K. and New Zealand). As we see that India is in a unique position by having the largest population that speaks English in the whole world. (Manivannan, 2019)

The English language is another official language, that has contemplated as a foreign language for a very long time. Nevertheless, everything has changed. The influence of the English language has grown enormously, since independence from the British. It is hard to state the specific number of Indian people, who understand the English language, use it, read it and write. However, English has excellent power and a decent quality like a local language.

According to Table 1, changes in the usage of English language among local people in India. The following figures show a tremendous increase in spreading English every decade. People started considering it as their mother tongue. Accounted in the following table. (See Table 1.)

Table 1.

Growth of English language in India.

\begin{tabular}{lllllllllll}
\hline Language & \multicolumn{3}{c}{ People who changed their mother tongue } & \multicolumn{5}{c}{ Decadal percentage increase \% } \\
\cline { 2 - 11 } & 1971 & 1981 & 1991 & 2001 & 2011 & 1971 & $1981-$ & $1991-$ & $2001-$ \\
& & & & & & - & 1991 & 2001 & 2011 \\
& & & & & & 1981 & & & \\
\hline English & 191,595 & 202,440 & 178,598 & 226,449 & 259,678 & 5,66 & 11,78 & 26,79 & 14,67 \\
\hline
\end{tabular}

The Indian nation made a hard decision, whether to choose English as a national language or not since this language had an opposing language, such as the Hindi language. In 1965, there was an effort to make Hindi language as an official national one, but it failed when society from the southern state of the country aggressively argued against it. There were some provisions taken in the Constitution of India, which has improved the role of English language alongside Hindi for official purposes. The government in India made a compromise and recognised the English language as a secondary official language. Nowadays, the official language is English, so in four states (Nagaland, Meghalaya, Manipur, Tripura) and eight union territories (Delhi, Chandigarh, National Capital Territory, Andaman and Nicobar Islands, Dadra and Nagar Haveli, Pondicherry, Lakshadweep, and Daman and Diu). We can see all these territories on the map below. Due to some linguistic and religious differences, which are the most critical causes for all disagreements among the local people in India. English upholds the mixture of different nations while connecting all people. English plays the role of the linguistic tool, that unites one part of the country to another. (Manivannan, 2019) 


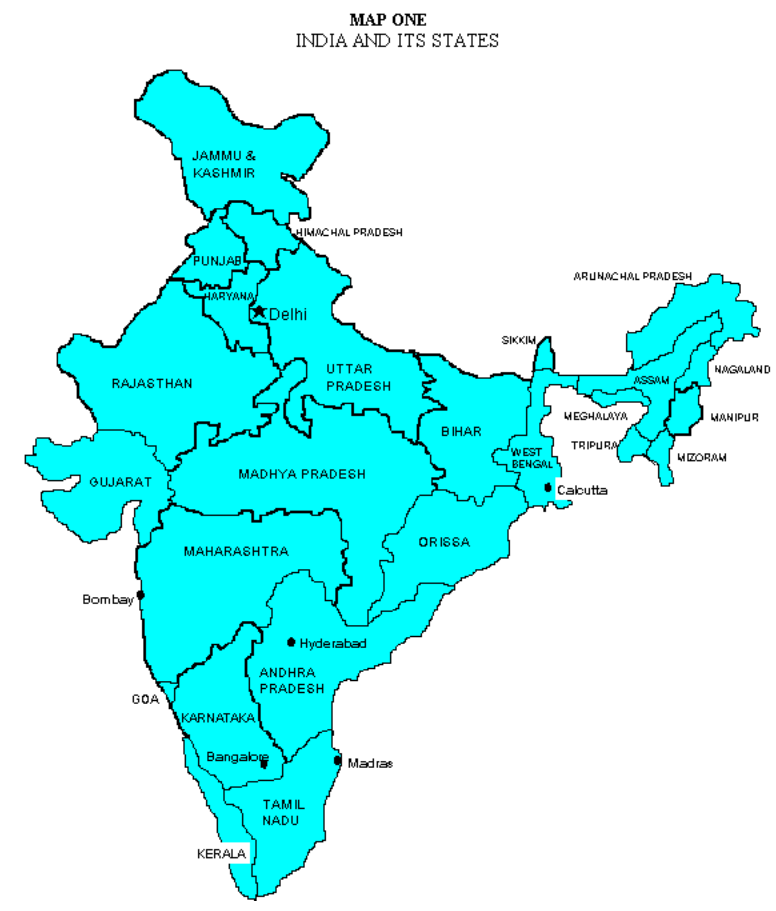

Graphic 1. Source: compiled by the authors according to the materials: Sanjeev Singha, Tency Josea, Ann Versportenb, Sharmila Sengupta, P. Finia, Mike Sharlandd, R. Krishna Kumara and Herman Goossensb, (January 2014), "A point prevalence surveillance study from pediatric and neonatal specialty hospitals in India", Journal of Pediatric Infectious Diseases 9(3):151-155, DOI: 10.3233/JPI-140429

English in India has two main reasons for existence. First of all, it accommodates a linguistic device for administrative integrity, prompting locals who speak various languages to be united. Second, the English language functions as a much broader communication tool, including different nations across a vast area.

Commonly, the English language is used by Indian people as a 'linking' tool, and it became almost the first language for the well-educated local people. In India, for those who speak more than one language, English is now the second one. It is a bond, which helps to connect several different segments of their society. Furthermore, English is a linguistic tool, which connects India with other major countries of the world. (Wiltshire, 2005, Manivannan, 2019)

As English is the standard now, and it is essential to learn more about it. It is trendy in all spheres (for example, business) having its cultural reasons. It is also widely used on the Internet and for communication with different parts of the world. It is also a standard approved by various organisations and broadly used by technology industries.

One of the most prime features of Indian bilingualism is that it is complimentary. Therefore, some can use one language at home and another in their neighbourhood. Furthermore, Hindi and English languages are part of the linguistic range for a specific number of Indian people. Thus, we can say that this linguistic diversity is not a coincidence, which helps to gain various cultural characteristics of the whole nation.

According to the decennial Census in table 1, the tendency from 1971 to 2011 shows an increasing number of people that use English, which relatively means an increase of usage of local Indian languages. Generally, English is a second language for most locals who start using 
English, when their mother tongue is the same as the state, otherwise regional language is the second language.

The importance of the English language is increasing suggested to study it in every state which should be positively taken up as an individual lesson. Recently, members of the National Council of Educational Research and Training (NCERT) started advocating for a curriculum, which would allow pupils from first grade to fifth to take no more than two books. However, it is still hard to resolve, as there is more than one language to study. Thus, educational authorities ought to prepare a specific academic plan for primary education in India. Members of NCERT are sure that it can help children to develop their personality and character. For more information, we can consider the next picture (see Pic. 2 below), which shows the popularity of English among males and females, comparing the same data in Asia and the global world.

\section{English by gender}
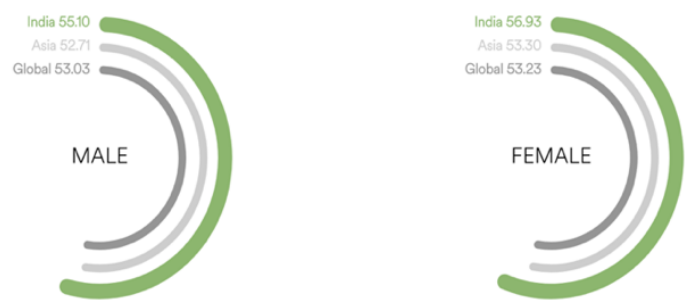

Pic 2. Source: compiled by the authors according to the materials: EF English Proficiency Index https://www.ef.com/wwen/epi/regions/asia/india/

Nevertheless, NCERT still has to consider an ideal academic plan. One of the questions raised is the purpose of language in education. In recent years the students' competence in using languages has declined. However, there is no confirmation about the availability of learning languages, which would indicate if students of different educational levels are less competent than those who completed their studies several decades ago. Nevertheless, it is highly necessary to improve language skills, which is showing further competence in cognitive development and learning. For more information, we can consider the following picture (Pic. 3 below), showing the English Proficiency Index (EPI). It shows India's ranking ( $34^{\text {th }}$ place) among 100 countries, where the English language is spoken.

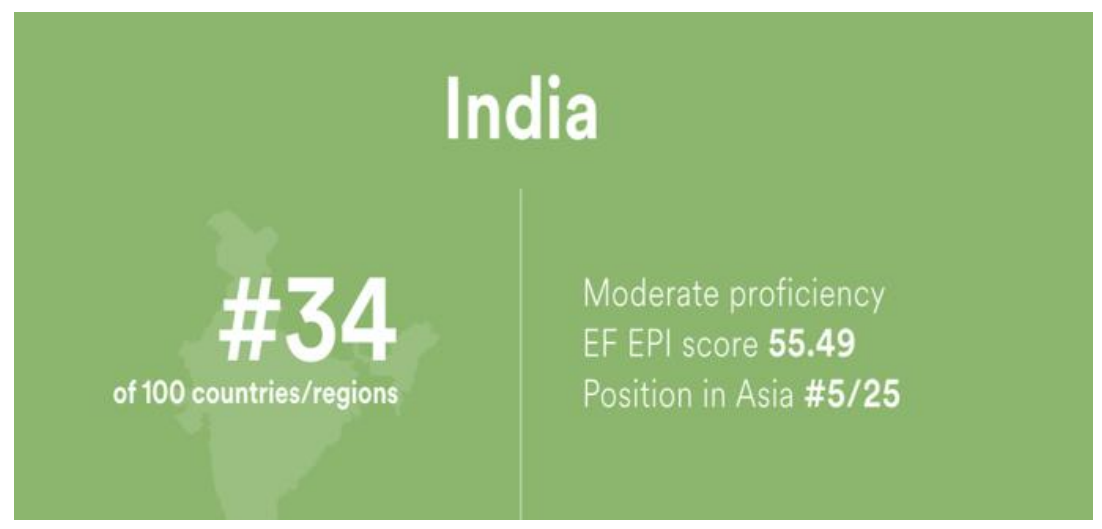

Pic 3. Source: compiled by the authors according to the materials: EF English Proficiency Index https://www.ef.com/__ /media/efcom/epi/2012/full_reports/ef-epi-2012-report-master-lr-2 
As we know, English has been spoken in India for a long time but, still, there are some specific developments in a dialect which is because of the influence of regional languages. As English became a part of Indian society, people try to speak and use everywhere. Some speak in British and others in an American accent.

The issue of regional peculiarities is of particular significance, for instance, in professional communication, since they often help to identify more or less accurately a speaker's origin, or place of residence, or professional domain. If language learners want to be linguistically, culturally competent and well prepared for efficient communication with a particular category of people, at that point, they should also study at least the linguistic basics of the local languages. (Malyuga et al., 2019).

\section{Features of pronunciation in Indian English}

\section{Consonants.}

In Indian regional languages, there is a lack of the voiced palatal or postalveolar sibilant [d]], as in "pleasure" and also a lack of affricates. The pronunciation of Indian English affricates [t] $]$ and [dz] are related to palatal plosives without the following friction.

Phonetics and Phonology Consonants [r]:

Due to the presence of regional languages, there are several variations of Indian English. Nevertheless, Indian English pronunciation is considered as non-rhotic. Words like "spark" and "world" having the sound [r] are not pronounced but it is well pronounced when it comes at the end of the word, for example, an actor or a vowel followed in the beginning, for example, a friend. In Indian English, the sound [r] may be realised as a frictionless alveolar approximant or as an alveolar tap.

\section{The labio-dental approximant [v]:}

Indian English has no difference between the sounds $[\mathbf{v}]$ and $[\mathbf{w}]$. There is no difference in the sounds $[\mathrm{v}]$ and $[\mathrm{w}]$ in Indian English. So, the sound $[\mathrm{w}]$ is produced by rounding lips and without making contact of teeth and lips, but the sound [v] is produced by the help of upper teeth with a lower lip. In Indian English, sound [v] and [w] is produced by upper teeth when it is closed by the bottom lip, without touching before moving away.

Th sound $[\theta]$ and $[ð]$ :

These particular sounds are usually tricky for Indian English speakers. In the standard Indian English pronunciation, the sound which is voiceless [ $[\boldsymbol{\theta}]$ is sometimes pronounced, on the other hand, the sound which is voiced [ð] is almost absent. Because of it, it creates misunderstandings for native listeners to understand, when Indian speakers substitute $[\theta]$ which is the aspirated voiceless dental plosive [th] and [ð] is substituted which is he unaspirated voiced dental plosive $[\mathrm{d}]$. $[\mathrm{t}]$ and $[\mathrm{d}]$.

Indian English uses retroflex plosives of sounds [T] and [D] despite alveolar plosives like

In the speech of some English speakers, syllables [I], [m] and [n] are usually substituted by the voiced consonant clusters. 
In R.P. sound [r] occurs just before a vowel, while Indian English indicates a very sharp as well as a clear alveolar trill in all word positions.

Phonemes [p], [t], and [k] are slightly aspirated in R.P. when used in a word or syllable at the initial position. However, contrasting Indian English, the difference between aspirated and unaspirated plosives is phonemic. Therefore, in such situation, Indian English uses the equivalent unaspirated voiceless plosives [p], [t], [k] instead of [ph], [th] and [kh].

Vowels.

Monophthongs.

In the standard Indian English pronunciation, the two central vowels [0] and [ $\mathbf{\Lambda}]$ are not typically distinguished. Thus, both sounds are pronounced as [o].

Diphthongs.

There are six diphthongs in standard Indian English pronunciation: [ı] as in peer, [0ə] as

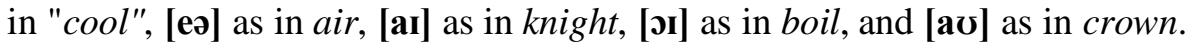

Though, the diphthongs [er] and [əo], as in nail and sole, that are used in British RP, are frequently substituted by long versions of the monophthongs [e:] and [o:] in Indian English. Moreover, in non-standard Indian English, many diphthongs are converted to a long vowel plus [r], so poor is [pur], beer is [bir], tour is [tur], pear is [per]. (Gargesh, 2004)

Morpho-phonology.

When the plural indicator on nouns follows an alveolar palatal fricative or affricate, it is pronounced as sounds [zz] or [ [z] in R.P., similar to the words bridges or kisses. Though, in Indian English, the plural indicator is recognised as [s] or [عs] sounds with the final sibilant devoiced. Besides, the past tense indicator is recognised as [d] or [ [ dd] sounds depending on the word. If the final consonant of the word is voiceless such as in a trap, then the past tense indicator is voiced in Indian English. Thus, the word trapped is pronounced as [træpd] in Indian English. (FerrierReid, 2014)

\section{Consonant clusters.}

Consonant cluster reduction is expected in standard Indian English pronunciation since Indian languages do not use consonant clusters. For instance, they pronounce the word acts as [æks]. Moreover, there is no syllabic consonant in words such as bottle in most dialects. Instead, an intrusive sound shwa is inserted. Though, high-frequency words such as film are commonly pronounced as [film] in standard Indian English pronunciation but may be produced as [filəm] in Indian English. (Pandey, 1994; Wells, 1982)

\section{Features of vocabulary and translation}

English plays an important role and has a specific status in India. English is an official language due to this reason it is widespread around India. It is widely used in the public and private institutions, mass media broadcasting, educational institutions, even in the parliament and judiciary courts of India. Thousands of international companies recruit Indians directly from the educational institutions not only because of education, culture or intellect but also because of fluent English. India comes in third place as spoken English. Nevertheless, still, people speak in Indian English, which is different than British or American, which has several strong dialects, accents and word phrases. 
Hindi is a widely spoken language in India having a massive contrast on English makes it Hinglish (a combination of Hindi and English), that is why the statistic influence is easily visible in Indian English. So, if an Indian want to know the name of somebody, he /she will ask "what is your good name?" instead of asking "what is your name?" which sounds in Hindi "Aapka shubh naam kya hai?", where "Shubh" means good, which gives a priority and the polite way to ask someone's name. It means, if we translate "Aapka shubh naam kya hai?" in English, we just need to write "what is your name?". Similarly, if an Indian wants to say "This morning or last night", he/she will say "Today Morning or Yesterday night" which sounds "Aaj Subha and Kal Raat".

There are some specific vocabularies, which are used by Indians around the world sometimes become onerous to understand.

- Half -pants: Instead of saying Shorts, Indians say Half-pants;

- Purse: purse which means wallet used by man and woman;

- Cinema hall: which means a cinema or movie theatre;

- English Knowing: a person who speaks English;

- Matrimonial: it is an ad, which is used in a newspaper column or website to find or purpos a marriageable partner;

- Press person: a person who works in the press;

- Revert: its means to answer back with some information;

- Chain-snatching: Pickpocketing;

- Redressal: redress;

- Upgradation: Level up or upgrading of something;

- Free ship: Full scholarship;

- Standard: grade, for example, he studies in ninth standard;

- Brinjal: Eggplat or aubergine;

- Curd: yoghurt;

- Finger chips: French fries;

- Small pastries; Ladyfingers;

- Current: electricity;

- Net: Internet.

There are many other words which are used by Indians which specify Indian English as a separate language.

British English is highly prevalent in India because of British colonisation among the older generation and American among the young. As Indian English is a hybrid language, it contains several words, phrases and terms used by Indians in their speech.

Yaar: which means buddy, bro, mate in India;

Mention not: means thanks somebody instead of a welcome, no problem;

Rubber: eraser;

Off it or on it, means switch it off or on;

Drop me: means give lift, for example: can he please drop us to Delhi?

Out of station: out of town;

Jee or Ji: are used as a suffix to show respect, for example, "Jone-ji";

Shree or Shreemati: are used as a prefix for man and woman, which means Mr or Mrs;

Progressive tense: the verbs which we cannot use in British or American English in progressive tense can be used in Indian English, for example, they are understanding you, or I am knowing her.

Uncle and Aunty are used to addressing strangers, neighbours, or relatives.

Arey: is a word which expresses positive emotion, for example, Arey what fantastic weather today! 
Aacha: is a word which expresses emotion as, Good, Ok, all right, but depends upon intonation.

A numbering system is also quite different in Indian English. Digits less than one hundred thousand is as similar to Standard English, but more than it would be expressed in another way, such as:

"One hundred thousand" in Indian English it would be "One lakh";

"One million to Ten lakh";

"Ten million to One crore"

\section{Results and discussion}

The research has identified the specification of Indian English as a separate language by the following results:

- English is spoken the most by Indian according to the number of speakers than any other country

- Indian English has transformed from British at the same time it has its own specific rules, sentence formation, idiomatic forms, translation pattern, specific vocabulary, grammar and pronunciation.

- There is lack of voiceless sounds such as [dz], [0] etc.

- Specific vocabularies which are used only in Indian English such as Brinjal which means aubergine, curd which means yoghurt etc.

- Indians tend to use "Lakh, Crore" officially for the Indian currency.

\section{Conclusion}

The results of this research have several important implications for future study and further development of international languages in different countries. More than 400 languages and 2000 dialects are spoken in India, among which Hindi and English are the official languages. Due to the colonisation of Great Britain, English is widely spoken, and it has a specific role in India. People start learning English since childhood. However, English is taught or spoken with a strong accent and linguistic contrasts because of Hinglish (a combination of Hindi and English) which becomes Indian English. Indian English is also recognised as a separate language by Google, which differentiates Indian English from British and American. Indian English has its phonetics, translation rules and vocabulary.

The research helps us to understand the phonology of Indian English, which needs much more work on the sound patterns. Intonation is a more or less neglected field. To address some of the issues and improve pronunciation of English, Indians need attentive practice, feedback from a teacher or trained native speaker. Accent changes after every $20 \mathrm{~km}$ in India, because of it, Indian English accent also changes. India has to set an official pattern or set of rules which will specify Indian English so that every Indian can speak in a particular set of linguistic rules, as the U.S.A. does it, or follow only the original British English. Although, the current research showed that it would be a mixture of several languages forever, which will be completely different from original English.

\section{Acknowledgments}

The publication has been prepared with the support of the «RUDN University Program [The program aimed to boost the competitiveness of Peoples' Friendship University of Russia (RUDN University) among the world's leading research and education centers in 2016-2020]» (recipients Grishechko Elizaveta Georgievna, Gaurav Sharma and Zheleznova Kristina Yaroslavovna, scientific research). 


\section{References}

Aleksandrova, O. V., Mendzheritskaya, E. O., \& Malakhova, V. L. (2017). Dynamic changes in modern English discourse. Training, Language and Culture, 1(1), pp. 92-106. DOI: 10.29366/2017tlc.1.1.6

Baldridge, J. (1996). Reconciling Linguistic Diversity: The History and the Future of Language Policy in India. Retrieved from https://www.ling.upenn.edu/ jason2/papers/natlang.htm

Bansal, R. K. (1990). The pronunciation of English in India. In S. Ramsaran, Studies in the Pronunciation of English: A Commemorative Volume in Honour of A. C. Gimson (pp. 219-300). London: Routledge.

Census of India (2011). Retrieved from Internet Archive Wayback Machine: https://web.archive.org/web/20180627064326/http:/www.censusindia.gov.in/2011Cens us/C-16_25062018_NEW.pdf

Constitutional Provisions: Official Language Related Part-17 of The Constitution of India". (July 1, 2015.). Government of India: Department of Official Language.

EF English Proficiency Index (2020). https://www.ef.com/wwen/epi/regions/asia/india/

$\mathrm{EF}$

$$
\text { English }
$$

Proficiency

Index. https://www.ef.com/_/ /media/efcom/epi/2012/full_reports/ef-epi-2012-reportmaster-lr-2

Ferrier-Reid, L. J. (2014). "INDIAN ENGLISH.", 4/12/2013. Phonologics.

Gargesh, R. (2004). Indian English: Phonology. In K. B. E W Schneider, A Handbook of Varieties of English, Phonology (Vol. 1, pp. 993-1002). Berlin: Mouton de Gruyter.

Joseph, M. (2011, February 16). India Faces a Linguistic Truth: English Spoken Here. New York Times

Kharkovskaya, A.A. Ponomarenko, E.V., \& Aleksandrova, O.V. (2020). Language picture of the world: the Global Language Monitor project. European Proceedings of Social and Behavioural Sciences EpSBS, Vol. LXXXIII: PhR 2019, 62-68. DOI: 10.15405/epsbs.2020.04.02.8

Malyuga, E., Maksimova D., \& Ivanova, M. (2019). Cognitive and discoursive features of speech etiquette in corporate communication. International Journal of English Linguistics, 9 (3) (pp. 310-318).

Manivannan, D. G. (2019, December 12). English as a National Foreign Language. India.

McGee, P. (2019). Cross-cultural pragmatic failure. Training, Language and Culture, 3(1), 73-84. DOI: $10.29366 / 2019$ tlc.3.1.5

Ministry of Home Affairs. (2019). "THE OFFICIAL LANGUAGE POLICY OF THE UNION". Retrieved from Department of Official Language: http://rajbhasha.nic.in/en/officiallanguage-policy-union 
Pandey, P. K. (1994). On a description of the phonology of Indian English. In R. K. Khanna, Second Language Acquisition. Socio-cultural and Linguistic Aspects of English in India. Research in Applied Linguistics (Vol. 1, pp. 198-207). Delhi: Sage.

R.L.G. (2011). "When does it stop being a foreign language?". The Economist. https://www.economist.com/johnson/2011/02/18/when-does-it-stop-being-a-foreignlanguage

Rai, D. K. (2017). The Challenges of Spanish Language Teaching in Multilingual India: A Case Study of Delhi. Pedagogical Research, 2(2), https://doi.org/10.20897/pr/80950.

Sanjeev, S., Tency, J., Ann V., Sharmila S., P. F., Mike, S., Krishna, K. and Herman, G. (2014). "A point prevalence surveillance study from pediatric and neonatal specialty hospitals in India", Journal of Pediatric Infectious Diseases 9(3):151-155, DOI: 10.3233/JPI-140429

Wells, J. C. (1982). Accents of English. Cambridge: Cambridge University Press.

Wiltshire, C. R. (2005). The "Indian English" of Tibeto-Burman language speakers. (Vol. 26). English World-Wide. 